Article

\title{
A Seed Coating Delivery System for Bio-Based Biostimulants to Enhance Plant Growth
}

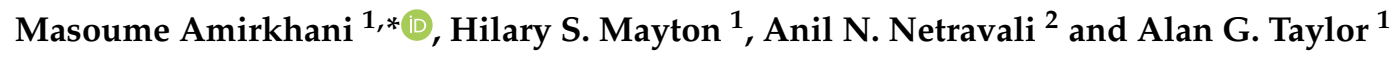 \\ 1 SIPS, Cornell AgriTech, Horticulture Section, Cornell University, Geneva, NY 14456, USA; \\ hsm1@cornell.edu (H.S.M.); agt1@cornell.edu (A.G.T.) \\ 2 Department of Fiber Science and Apparel Design, Cornell University, Ithaca, NY 14850, USA; \\ ann2@cornell.edu \\ * Correspondence: ma862@cornell.edu
}

Received: 26 August 2019; Accepted: 24 September 2019; Published: 26 September 2019

check for updates

\begin{abstract}
A novel delivery method for the application of bio-based biostimulants as seed coatings was developed using different sources of liquid and powder forms of vermicompost and soy flour. Micronized vermicompost (MVC) and soy flour (SF) were mixed in different combinations as dry seed coating blends and applied using rotary pan seed coating equipment. The physical properties of coated seeds were measured, and as binder concentration increased, coating strength increased. The rates and percentages of germination of the newly developed coating formulations of SF+MVC did not decrease the germination parameters and were not significantly different than the control. However, the SF, SF with concentrated vermicompost extract, and SF + MVC from dairy manure increased the seedling vigor index by 24, 30, and 39 percent, respectively, compared to the control. Plant biometric parameters and nitrogen uptake per plant were also significantly higher for SF and SF+MVC coated seeds than the control, in a greenhouse environment. This is the first seed coating study to show an enhancement of plant growth with vermicompost, and vermicompost in combination with a plant-based protein that serves as a dry seed coating binder and biostimulant, respectively. Seed coatings developed in this study can serve as a model for development of the delivery systems of seeds for the application of bio-based biostimulants to enhance early plant growth.
\end{abstract}

Keywords: seed treatment; vermicompost; soy flour; sustainable agriculture

\section{Introduction}

Biostimulants, broadly defined, are a diverse range of materials which, when applied to plants, seeds, and growing substrates in small quantities, have the capacity to enhance physiological processes in plants that provide benefits to growth and development, or can reduce plant stress [1]. Investigations on the use of biostimulants have been gaining interest worldwide, since they have the potential to minimize the negative environmental impacts associated with applications of agrochemical pesticides and fertilizers [2]. Various categories of plant biostimulants include microbial inoculants, beneficial bacteria and fungi, plant and animal-based protein hydrolysates, and other nitrogen containing compounds, such as humic and fulvic acids, biopolymers, seaweed, and botanical extracts [1].

Recently, several studies on the utilization of biostimulants in agriculture have been initiated to evaluate their influence on crop quality and the growth enhancement of plants. The use of biostimulants at a low dosage decreases the risk of phytotoxicity and can reduce the application of high concentrations of agrochemicals, which contaminate soil and water [3,4]. Foliar applications of biostimulants have been investigated on a range of horticultural crops, while little research has been conducted on biostimulant seed treatments. In addition, the physiological mechanisms associated with the nutrient uptake of biostimulants via seed coating have not been elucidated. The application 
of biostimulants to seeds has the potential to promote plant growth at an early stage, while using low doses [5]. Previous investigations have demonstrated that seed treatments with growth regulators, micro and macronutrients, amino acids, and beneficial microbes, or other biostimulants, can enhance plant growth at the time of sowing [5-9].

Vermicomposting is a process that utilizes earthworms to convert biodegradable organic wastes such as animal manure and plant debris, into a humus-like compost product. The biostimulant properties of vermicompost have generally been attributed to the presence of substances with phytohormonal activity and humic and fulvic acids [10]. In addition, the mineralization of carbon during the vermicomposting process results in increases in nitrogen, phosphorus, and other macro and micronutrients compared to the original substrates, and can enhance bioavailability of these nutrients when vermicompost is applied as a supplement to plants [11] Hussain and Abbasi (2018) recently published an extensive review on the efficacy of vermicompost on seed germination and plant growth. The paper reviewed over 250 investigations and discussed several methods used to apply both animal and plant based vermicompost to enhance plant growth; however, there were no reports on the application of vermicompost as a seed coating [11]. Therefore, vermicompost and vermicompost products warrants research to investigate their biostimulant properties applied as seed treatments, so it became the focus of this study.

Seed coating technology is focused on the development of the accurate and uniform application of specific, and often novel, materials onto seeds. The application of active ingredients as a seed coating is more precise and eliminates the need for spraying products over entire fields. A seed coating facilitates uniform seeding and can include many types of materials, such as pesticides, and other amendments required at planting [12]. Modern seed coating technology allows the delivery of many types of materials that can enhance plant growth and improve seedling stand establishment at reduced application rates compared to the foliar or soil applied methods [13,14]. Commercial requirements for a new seed coating formula as a competitive seed treatment product in the market demand that the products meet high safety standards. The technology needs to be safe and convenient for growers, have minimal impact on the environment, and active ingredients should be applied the lowest possible dose rate. These safety requirements are driving the development of improved formulations in seed enhancement technologies $[15,16]$.

The objective of this study was to develop a new and efficient seed coating delivery method to investigate the potential biostimulant effect of vermicompost, a nutrient rich medium, in combination with soy flour (SF), a plant-derived protein, when applied as a novel seed-coating blend, without using a liquid binder. Laboratory and greenhouse experiments were conducted to evaluate the seed coating formulations with different binders and fillers and assess the influence of vermicompost and soy flour, alone or in combination, on broccoli seeds.

\section{Materials and Methods}

\subsection{The Development of Biostimulant Seed Coating Delivery System Formulations}

A series of experiments were designed to test and develop the seed coating formulation combinations in order to evaluate the biostimulant materials. Three micronized vermicompost products (MVC1 and 2, Worm Power, Avon, NY, USA and MVC3 Terra Vesco, Sonoma Valley Worm Farm, Sonoma, CA, USA) and a concentrated vermicompost extract (CVE) (from Worm Power and concentrated by Caloris Engineering, Easton, MD, USA) were evaluated as biostimulant materials, along with defatted soy flour 7B (SF), a plant-derived protein provided by Archer Daniels Midland Co., Decatur, IL (Table 1). All seed coating solid materials used in this study were sieved to a fine particle size $<75 \mu$ by passing through a \#200 mesh sieve. An analysis of seed coating biostimulant materials was conducted by Cornell Soil Health Nutrient Analysis Laboratories [17]. Other solid particulate materials, including diatomaceous earth (DE) obtained from Perma-Guard, Inc, Albuquerque, NM, and xanthan gum (XG) (Bob's Red Mill Natural Foods, Milwaukie, OR, USA), were used to develop 
the seed coating formulations. SF and XG also served as solid particulate, dry binders in seed coating blends. Based on our previous seed coating research [5], different proportions by weight of SF and DE or MVC were tested (Tables 2-5).

A laboratory-scale rotary pan coater, R-6 (Universal Coating Systems, Independence, OR, USA) was used to coat the seeds for all four experiments in this study (Appendix A, Figure A1A). Twenty grams of seeds were used for each seed coating treatment and all seed coatings were applied as dry powder to seeds with a $30 \%$ build-up of seed weight. The first experiment was designed to determine the best seed coating ratio formulations. In this experiment SF, DE, and MVC2 were applied in different ratios (Tables 2 and 3). Based on germination and seedling growth measurements, the optimal proportion of SF and DE was found to be 30:70. The second experiment was designed to evaluate the influence of the different biostimulant substrates listed in Table 1 on plant growth enhancement in the laboratory (Table 4). In all experiments using the R-6 seed coater, the filler powder to be coated was dusted onto seeds followed by alternate applications of water $(10 \mathrm{~mL})$ as a wetting agent; however, in experiment 2, water was replaced by liquid concentrated vermicompost extract (CVE). As mentioned earlier, SF and XG were used as dry binders. Coated seeds were then air dried on a lab bench at ambient temperature $\left(\sim 20^{\circ} \mathrm{C}\right)$.

In the third experiment, MVC2 and SF, selected from experiment 2, were applied to the seeds alone and in combination, in an effort to investigate their additive interactions on seed germination and seedling growth). Seed coating treatments for each experiment consisted of selected blends of two components, soy flour and diatomaceous earth (SF+DE), soy flour and vermicompost (SF+MVC), xanthan gum and diatomaceous earth $(\mathrm{XG}+\mathrm{DE})$, or xanthan gum and vermicompost (XG+MVC), in ratios of 30:70 on a weight basis (Table 5). The two best treatments (SF+DE and 30:70 SF+MVC2) were selected to be tested in a greenhouse in experiment 4 (Table 6). The total amount of SF and vermicompost was calculated for each coating treatment on a single seed basis [5], and then expressed as mg of nitrogen applied per seed (Figure 5).

\subsection{The Mechanical and Hydration Properties of the Seed Coatings}

Physical properties of coated seeds measured from experiments 1,2, and 3 were evaluated using two methods. A Ro-Tap sieve shaker (The W.S. Tyler Co., Cleveland, OH, USA, 2009) was used to measure the weight loss [5] after mechanical shaking and a texture analyzer (TA-XTplusC, Texture Technologies Corp., S. Hamilton, MA, USA, 2018) (Figure 1) was used to measure compressive strength of coated seeds. A total of 10 replications of a single coated seed was used to obtain the peak load force $(\mathrm{N})$ and time to decay $(\mathrm{TD}, \mathrm{s})$ required to fracture each seed coating treatment. Texture analyzer software (Exponent Connect, version 7.0.2.0, S. Hamilton, MA, USA, 2018) was used to record force and time to decay data [18]. Seed coating integrity (hydration test) from the three experiments was evaluated by soaking coated seeds in water while measuring the seed coat disintegration time (DT $\min )[5]$. 

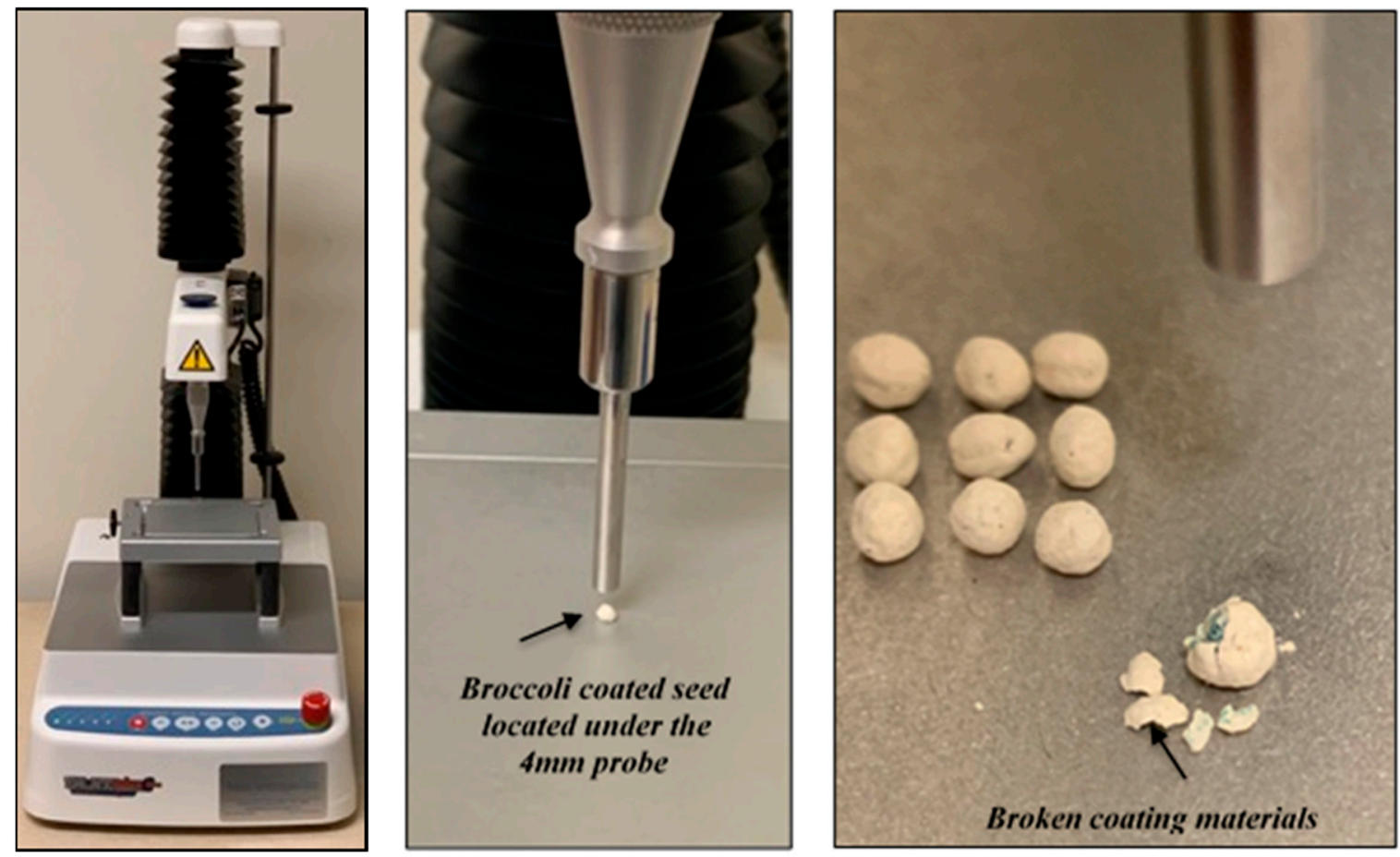

Figure 1. Texture analyzer (TA-XTplusC), to measure compressive strength (Force, $\mathrm{N}$ ) and time required to totally decay and break down the seed coat.

\subsection{Plant Material, Germination, and Plant Growth Measurements in the Laboratory and Greenhouse}

A seed lot of broccoli var. 'Italica' (Brassica oleracea L.) ('Durapak'), provided by Syngenta Seeds, Boise, ID, was used for all experiments in this study. Germination tests were conducted in the laboratory by placing four replicates of 50 seeds between germination paper towels $(30.5 \times 45.7 \mathrm{~cm}$, Anchor Paper Company, St. Paul, MN, USA) moistened with water, with two layers beneath and one placed above the seeds. The paper towels were then rolled up and positioned upright in a germinator (Percival germinator, Model I-36LL, Perry, IA, USA, 2016) maintained at $20 / 30^{\circ} \mathrm{C}$ with a $16 / 8$ hour dark/light photoperiod, respectively [19]. Seed germination (radical emergence $>2 \mathrm{~mm}$ ) was recorded every $24 \mathrm{~h}$ for one week. Total germination percentage (Gmax, the number of germinated seeds after 7 days), germination uniformity (GU $=\mathrm{T} 90-\mathrm{T} 10)$ ( $\mathrm{T} 90$ is the time in hours for $90 \%$ of total germination and $\mathrm{T} 10$ is the time in hours for $10 \%$ of total germination) [20] were recorded, and germination rate (T50, the time in hours for $50 \%$ total germination) was calculated according to Equation (1) [21] shown below, where $\mathrm{N}$ is the final number of germinated seeds, and ni and nj are total number of seeds germinated at time ti and $\mathrm{tj}$, where $\mathrm{ni}<(\mathrm{N}+1) / 2<\mathrm{nj}$. Shoot and root lengths, and dry weight, were measured ten days after placing seeds in the paper roll towels. Four replicates of 50 seeds of each treatment were recorded for each treatment. Seedling vigor index (SVI) was calculated as per Abdul-Baki and Anderson [22].

$$
\mathrm{T} 50=t i+\left[\frac{(N+1) / 2-n i}{n j-n i}\right](t j-t i)
$$

Plant growth and development characteristics in experiment 4 were conducted in a controlled greenhouse located at Cornell AgriTech, Geneva, NY, maintained at $24 / 21^{\circ} \mathrm{C}$ with a $14 / 10 \mathrm{~h} \mathrm{light} / \mathrm{dark}$ photoperiod. Two seeds of each treatment were sown in a $10 \times 10 \mathrm{~cm}$ plastic pot that contained Sunshine Mix \#8/LC8 (Sun Gro Horticulture, Agawam, MA, USA), a commercial greenhouse substrate. One week after planting, each pot was thinned to one plant. There were 25 plants for each treatment ( 3 treatments $\times 5$ replicates $\times 5$ samples per replicate $=75$ plants) placed in a completely randomized design.

Four weeks after sowing, plant biometric data, including shoot height and width, root length, stage of leaf development (the percentage of plants with six true leaves, L6D), leaf surface area, and shoot 
and root dry weight, were recorded (Table 6). Leaf surface area was measured using a CI-202 Leaf Area Meter (CID Bio-Science, Camas, WA, USA, 2011). Roots were separated from shoots and gently washed to remove growing media. Plant materials were oven dried at $105^{\circ} \mathrm{C}$ for 3 days to obtain the dry weight. Plant growth and vigor indices were calculated with the following equations [22,23].

$$
\begin{gathered}
\text { Growth Index }=\frac{\text { Plant height }}{2}+\frac{(\text { Plant Width } 1+\text { Plant Width } 2)}{4} \\
\text { Plant Vigor Index }=\frac{\text { Total emergence } \times \text { Plant length }}{100}
\end{gathered}
$$

\subsection{Leaf Chlorophyll Measurement}

For the plant growth evaluations conducted in the greenhouse (experiment 4), plant chlorophyll concentrations were measured using a hand-held optical Konica Minolta, model SPAD-502 (Spectrum Technologies, Plainfield, IL, USA, 2006). The SPAD-502 chlorophyll concentration meter measures the transmission of two wavelengths of radiation through plant leaves: red at approximately $650 \mathrm{~nm}$, and near infrared (NIR) at approximately $900 \mathrm{~nm}$. Four weeks after planting, three SPAD-502 meter measurements were recorded per plant on the most recently expanded leaf of 25 plants for each treatment.

\subsection{Plant Nitrogen Content Analysis}

Dry leaf tissue samples from the greenhouse (experiment 4) were collected and ground to a particle size of $2 \mathrm{~mm}$ (with Wiley Mill, Arthur H. Thomas Co. Scientific Apparatus, Philadelphia, PA, USA) and total nitrogen content was measured. Five subsamples (100 mg) of ground leaf tissue of each treatment were sent to the Stable Isotope Laboratory (Cornell University, Ithaca, NY, USA) for nitrogen analysis. The total nitrogen content of leaf tissue was calculated by multiplying dry leaf weight by leaf nitrogen content, and the enhanced nitrogen per plant was calculated by the difference between the control and each coating treatment $[5,24]$.

\subsection{Statistical Analysis}

Experimental data were subjected to a one-way analysis of variance (ANOVA) to analyze the effect of treatments and means were separated by a least significant difference (LSD) test at a significance level of $p<0.05$. Coefficients of determination $(r)$ were computed to show linear relationships of mechanical properties and the physical integrity of seed coats with germination characteristics; and plant vigor index with the growth index from experiment 4 and with the seedling vigor index from experiment 1. Statistical analyses were performed with JMP Pro 14 (SAS Institute, Cary, NC, USA, 2018).

\section{Results and Discussion}

\subsection{Analysis of Seed Coating Materials}

Results of nitrogen composition of the potential biostimulant seed coating materials analyzed by the Cornell Soil Health and Nutrient Analysis Laboratories are shown in Table 1. Data from the nutrient analysis show that MVC1 and MVC2 had almost twice the amount of $\mathrm{NO}_{3}+\mathrm{NO}_{2}(6560$ and $6812 \mu \mathrm{g} / \mathrm{g})$ that MVC3 had (3442 $\mu \mathrm{g} / \mathrm{g})$. Additionally, MVC1 had much higher available $\mathrm{NH}_{4}$ than MVC2 and MVC3, 199, 93 and $20 \mu \mathrm{g} / \mathrm{g}$ of $\mathrm{NH}_{4}$, respectively. The total nitrogen percentages were $3.6 \%$ for MVC2, 3.2\% for MVC1, 2.6\% for MVC3, and 8.0\% for SF. As the compost extract (CVE) was a liquid it is difficult to make any direct comparisons of total or available $\mathrm{N}$ from the nutrient analysis, but all values were less than the solid substrates. The SF used in these experiments was analyzed by Archer Daniels Midland (Decatur, IL, USA), so data were not directly comparable to the Cornell Health Analysis; however, SF had higher percentage of protein and total N compared to the vermicompost materials. In addition to the $\mathrm{N}$ nutrient analysis, the Cornell Soil Health laboratory 
evaluated the microbial respiration of the three vermicompost (MVC) products used in this study. Respiration was determined by measuring the $\mathrm{CO}_{2}$ evolved from individual vermicompost samples (all values are $>2.9 \mathrm{mg} \mathrm{CO} / \mathrm{g}$ soil) and results showed very high (100) levels of respiration from all samples (Figure A3). These data indicate high microbial activity in these nutrient rich materials.

Vermicompost products can carry diverse microbial populations, particularly fungi and bacteria. Aremu et al. [10] and Krishnamoorthy et al. [25] suggested that microbial activity could result in the production of significant quantities of mixtures of plant hormones, such as indole acetic acid, gibberellins, cytokinins, and auxins. Those, and other microbial activity, increase enzymatic activities in plants.

Table 1. The results of the nitrogen composition analysis of vermicompost and soy flour materials used as seed-coating, biostimulant-treatment formulations in this study.

\begin{tabular}{cccccc}
\hline Materials & Source & $\mathbf{N} \%$ & Protein $\%$ & $\mathbf{N H}_{\mathbf{4}} \boldsymbol{\mu g} / \mathbf{g}$ & $\mathbf{N O}_{\mathbf{3}}+\mathbf{N O}_{\mathbf{2}} \boldsymbol{\mu g} / \mathbf{g}$ \\
\hline MVC1 & Dairy manure & 3.2 & 6.38 & 199 & 6560 \\
MVC2 & Dairy manure & 3.6 & 7.15 & 93 & 6812 \\
MVC3 & Rice straw & 2.6 & 7.17 & 20 & 3442 \\
CVE & Dairy manure & - & - & $3.4 \mathrm{mg} / \mathrm{L}$ & $557 \mathrm{mg} / \mathrm{L}$ \\
* Soy Flour & - & 8.0 & 53.0 & - & - \\
\hline * N and Protein \% of soy flour provided by ADM (Archer Daniels Midland Co, Decatur IL, USA).
\end{tabular}

\subsection{Physical Integrity of Coated Seeds}

The mechanical and hydration properties, and physical integrity of the coated seeds were tested using three different methods. Increasing the proportion of SF in the filler of both SF+DE and SF+MVC2 treatments from $30 \%$ to $50 \%$, resulted in a decrease in weight loss during mechanical shaking with Ro-tap, and a significant increase in the time required in water to disintegrate the seed coatings (60 versus $126 \mathrm{~min}$ for $\mathrm{SF}+\mathrm{DE}$ and 78 versus 152 for $\mathrm{SF}+\mathrm{MVC} 2$, respectively; Table 2). The peak load force required to fracture the seed coat also increased significantly with an increase in the SF proportion in the filler (Figure 2 and Table 2). For example, the peak force and time to decay (TD) for the SF+DE 30:70 seed coating was 16.6 Newton $(\mathrm{N})$ and 0.39 seconds versus $19.1 \mathrm{~N}$ and 0.80 seconds for the SF+DE 50:50 combinations, respectively. This is due to the good adhesive characteristic of SF; the latter contains several polar amino acids [26,27].

Significant negative correlations were calculated between seed coating weight loss percentage and peak load force $\left(r=-0.98^{* * *}\right)$ and there was a significant positive correlation between disintegration time and peak load force $\left(r=+0.98^{* * *}\right)$ and time to decay $\left(r=+0.99^{* * *}\right)$ from seed coating formulations evaluated in experiment 1 (Appendix A, Table A2). The physical integrity of coated and pelleted seeds is important in any packaging, shipping, and sowing operation. When coated, treated seed are handled, a substantial amount of mechanical breakage and dust can be produced. These released dust particles can be potential health and safety hazard. As a result, determining the mechanical integrity of treated seeds is important when evaluating the characteristics of the seed amendment. In spite of this, very few studies on evaluating the physical quality of seed coatings have been published. There is no single test that is sufficient to assess all the features that contribute to the quality of a coated seed lot. Several physical and mechanical properties need to be evaluated. The Heubach dust-meter for quantifying the abrasion potential of seed coatings has been identified as the standard method to determine dust-off, especially that of pesticide-treated seeds; however, it only measures the very fine dust fraction [28,29]. Foque et al. [28] tested the mechanical integrity of several different corn and wheat seed treatments with a mechanical shaker (SM-30, Edmund Bühler GmbH, Germany). The total dust loads after mechanical shaking for wheat seeds from the Foque study, were three times more than was observed in this study for the SF+DE 30:70 (Table 2) seed coating treatment. Foque et al. [28] determined that the Heubach value (HV) for the wheat seed lot in their research met the standards of quality for treated seed used in Italy and France [28]. Although the wheat and broccoli seeds are 
very different in shape, size, and morphology, and these differences do affect the dust-off percentage, the quality of all coated seeds in this study indicated that the adhesiveness of dry binders used in all treatments were sufficient to avoid producing an overabundance of dust.

Table 2. The surface mechanical-property analyses and hydration tests of seed coating formulas used in experiment 1 of this study: weight loss (WL, \%), disintegration time (DT, min), compressive strength (Force, N) and time to decay (TD, s).

\begin{tabular}{ccccc}
\hline Treatment & WL (\%) & DT (min) & Force (N) & TD (s) \\
\hline SF+DE 30:70 & $1.6 \mathrm{C}$ & $60 \mathrm{D}$ & $16.6 \mathrm{C}$ & $0.39 \mathrm{C}$ \\
SF+DE 40:60 & $1.2 \mathrm{~B}$ & $110 \mathrm{C}$ & $18.2 \mathrm{~B}$ & $0.72 \mathrm{~B}$ \\
SF+DE 50:50 & $0.9 \mathrm{AB}$ & $126 \mathrm{~B}$ & $19.1 \mathrm{~A}$ & $0.80 \mathrm{~A}$ \\
SF + MVC2 30:70 & $1.4 \mathrm{~B}$ & $78 \mathrm{D}$ & $17.6 \mathrm{C}$ & $0.48 \mathrm{C}$ \\
SF + MVC2 40:60 & $1.2 \mathrm{~B}$ & $130 \mathrm{~B}$ & $18.8 \mathrm{~B}$ & $0.78 \mathrm{~B}$ \\
SF + MVC2 50:50 & $1.0 \mathrm{AB}$ & $152 \mathrm{~A}$ & $19.5 \mathrm{~A}$ & $0.91 \mathrm{~A}$ \\
\hline
\end{tabular}

Means within each column followed by the same letter are not significantly different from each other (least significant difference test, $p<0.05)$.

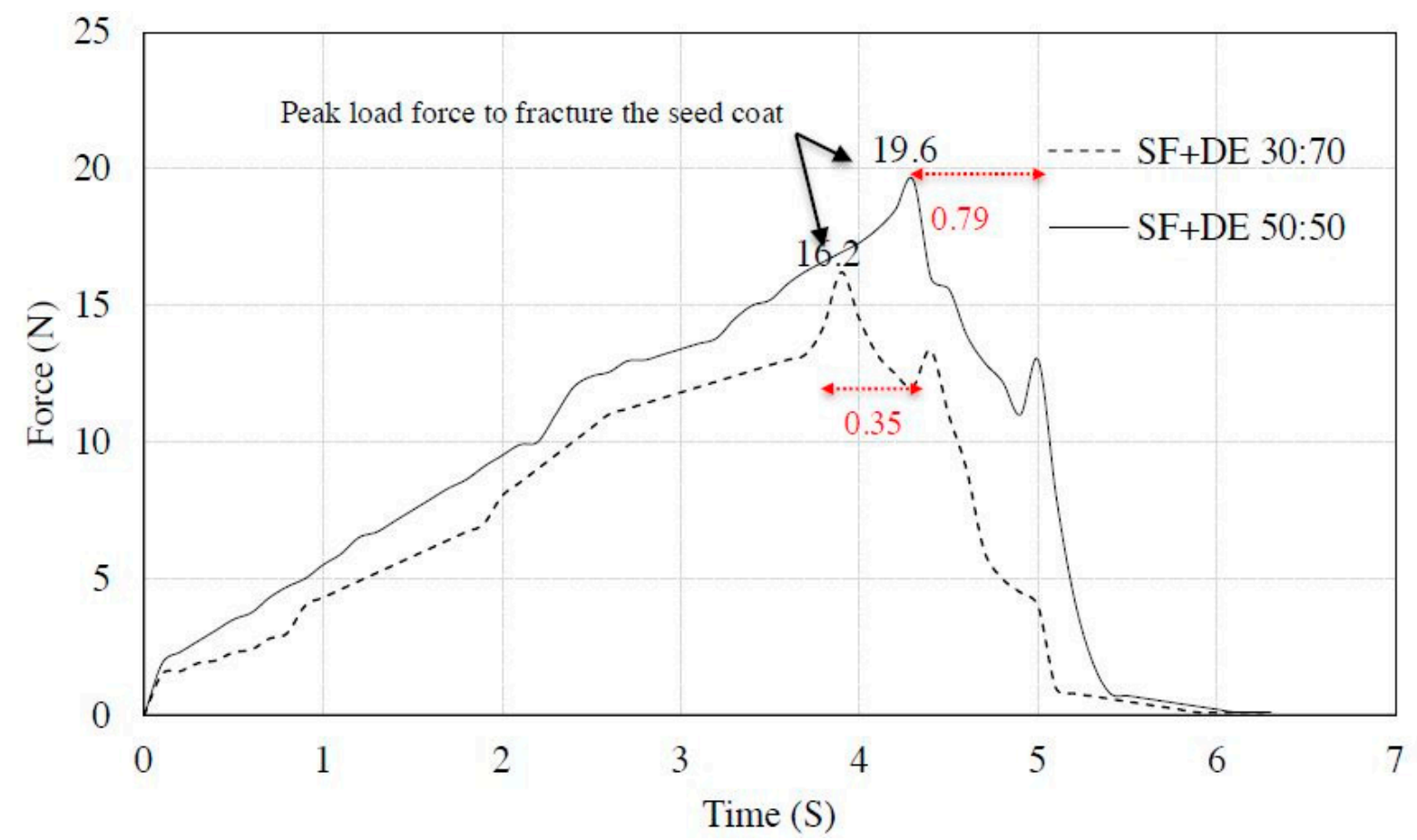

Figure 2. Example graph of the texture analysis of a single seed from the combination of soy flour and diatomaceous earth (DE) tested at room temperature. The maximum force value $(\mathrm{N})$ is a measure of coating strength. Red arrows show the time to decay and break down the seed coating (TD, s). Force and TD in Table 2 and Appendix A, Table A2, are the means of 10 seeds. (Equipment: TA-XTplusC, Texture Technologies Corp., S. Hamilton, MA, USA, 2018. Software: Exponent Connect, version 7.0.2.0, S. Hamilton, MA, USA, 2018).

\subsection{Germination and Plant Growth Measurements in the Laboratory and Greenhouse}

The seed germination and plant growth data from the first experiment designed to determine the most appropriate ratios of binder and filler, for the application of the biostimulant materials as a seed coating, are shown in Table 3. Both disintegration time and time to decay (Table 2) had a positive correlation with germination uniformity $\left(r=+0.99^{* * *}\right)$ and germination rate $\left(r=+0.93^{* *}\right)$ (GU and T50 in Table 3) (Appendix A, Table A1). These data indicate that a higher proportion of SF in the seed coating formulation resulted in harder coatings, but slower and more non-uniform germination. 
Table 3. Total germination (Gmax\%), germination uniformity (GU: T90 (90\% of total germination) $\mathrm{T} 10)$, germination rate $(\mathrm{T} 50)$, shoot and root length $(\mathrm{cm})$, and seedling vigor index $(\mathrm{SVI}=\mathrm{Gmax} \% \times$ seedling length) from controlled chamber germinator experiment 1.

\begin{tabular}{ccccccc}
\hline Treatment & Gmax (\%) & GU (h) & T50 (h) & Shoot (cm) & Root (cm) & SVI \\
\hline Non-treated & $97 \mathrm{~A}$ & $32 \mathrm{~A}$ & $33 \mathrm{~A}$ & $3.9 \mathrm{C}$ & $8.8 \mathrm{~B}$ & $12.3 \mathrm{C}$ \\
\hline SF+DE 30:70 & $96 \mathrm{~A}$ & $35 \mathrm{~A}$ & $34 \mathrm{~A}$ & $5.3 \mathrm{~A}$ & $11.3 \mathrm{~A}$ & $15.9 \mathrm{~A}$ \\
SF+DE 40:60 & $93 \mathrm{~B}$ & $45 \mathrm{~B}$ & $40 \mathrm{~B}$ & $5.4 \mathrm{~A}$ & $10.6 \mathrm{~A}$ & $14.8 \mathrm{~B}$ \\
SF+DE 50:50 & $90 \mathrm{~B}$ & $48 \mathrm{~B}$ & $44 \mathrm{~B}$ & $5.0 \mathrm{~B}$ & $8.7 \mathrm{~B}$ & $12.4 \mathrm{C}$ \\
\hline SF+MVC2 30:70 & $96 \mathrm{~A}$ & $32 \mathrm{~A}$ & $35 \mathrm{~A}$ & $5.7 \mathrm{~A}$ & $11.4 \mathrm{~A}$ & $16.4 \mathrm{~A}$ \\
SF+MVC2 40:60 & $92 \mathrm{~B}$ & $44 \mathrm{~B}$ & $44 \mathrm{~B}$ & $6.0 \mathrm{~A}$ & $11.1 \mathrm{~A}$ & $15.7 \mathrm{~A}$ \\
SF+MVC2 50:50 & $92 \mathrm{~B}$ & $50 \mathrm{~B}$ & $48 \mathrm{~B}$ & $5.8 \mathrm{~A}$ & $11.0 \mathrm{~A}$ & $15.4 \mathrm{AB}$ \\
\hline
\end{tabular}

Means within each column followed by the same letter are not significantly different from each other (least significant difference test, $p<0.05)$.

Results presented in Tables 2 and 3 clearly show the superiority of the treatments with a $30 \%$ proportion of SF mix with either DE or MVC2, as the dry binder provided an appropriate strength in the formula to hold the materials around the seed without impacting the total germination, germination uniformity, and rate (T50) compared to the non-treated control seeds. In addition, both treatments (regardless of the SF proportion) showed significant increases in shoot length when compared to the non-treated control (Table 3). The highest root length was measured for treatments with a 30\% proportion of SF mix with either DE or MVC2 (11.3 and $11.4 \mathrm{~cm}$, respectively) compared to the $40 \%$ (10.6 and $11.1 \mathrm{~cm}$, respectively), 50\% (8.7 and $11.0 \mathrm{~cm}$, respectively), and non-treated control $(8.8 \mathrm{~cm}$ root length; Table 3). The seedling vigor index (SVI) for both formulas of 30:70 SF+DE and SF+MVC2 was higher than the other treatments and non-treated control. The highest SF application rate resulted in the greatest seed coating strength, which had a negative effect on germination parameters (Gmax\%, T50, and GU) and also resulted in decreased SVI. Further research is needed to quantify the seed treatment, biostimulant application rate on plant growth and development.

The second set of experiments were designed to evaluate the vermicompost products from different sources (dairy manure and rice straw) to apply as a seed coating blend with SF and compare the germination variables and seedling growth parameters with SF and DE combination (SF+DE 30:70) with non-treated control seeds. Results (Table 4) in the germination roll towel test showed that the percent total germinated seeds, germination uniformity, and rate (T50) were not significantly different than non-treated control seeds. Shoot and root length, seedling dry weight (DWt g), and seedling vigor index, determined as indicators of plant performance, were measured 10 days after planting. Root length increased significantly $(17.2 \%$ to $23.6 \%)$ in response to all coating applications in comparison with the non-treated control seeds (Table 4). However, there were no significant differences between different coating formulas for the root length. The highest root length was observed in the SF+MVC2 treatment. Compared with the control, SF+DE significantly enhanced the shoot growth by $48.1 \%$, and the application of liquid concentrated vermicompost extract (CVE) in SF+DE+CVE significantly promoted the shoot growth by $66.6 \%(2.7 \mathrm{~cm}$ and $4.5 \mathrm{~cm}$ respectively). The application of each source of micronized vermicompost (MVC1, 2, and 3) products increased the shoot length from $100 \%$ to $114 \%$ compared to the non-treated control seeds (Table 4). Additionally, the highest seedling vigor index value was recorded for SF+MVC2, which was approximately $40 \%$ higher than the SVI of non-treated control.

Although there were no significant differences in root growth, all vermicompost seed coating blends (SF+MVC) enhanced seedling growth compared to the SF+DE and control (Table 4). These results indicate that both sources of compost (dairy manure and rice straw) enhanced the plant growth in combination with the SF, compared to the application of SF alone. Overall seedling performance was higher using the powdered MVC combined with SF than the liquid CVE. This was attributed to greater amount and percentage of N from MVC applied per seed than CVE. MVC1 and 2 had higher N\% than the MVC3 (Table 1); however, there were no significant differences measured from the different 
MVC products used in seed coating treatments for germination and seedling growth variables (Table 4, and Appendix A, Figure A2).

Table 4. Total germination (Gmax\%), germination uniformity (GU: T90-T10), germination rate (T50), shoot and root length $(\mathrm{cm})$, seedling dry weight $(\mathrm{DWt}, \mathrm{g})$, and seedling vigor index $(\mathrm{SVI}=\mathrm{Gmax} \% \times$ seedling length) from the evaluation of different vermicompost source materials in experiment two.

\begin{tabular}{cccccccc}
\hline Treatment & Gmax (\%) & GU (h) & T50 (h) & Shoot (cm) & Root (cm) & DWt (g) & SVI \\
\hline Non-treated & $98 \mathrm{~A}$ & 32 A & 36 A & 2.7 D & $9.3 \mathrm{~B}$ & $0.308 \mathrm{C}$ & $11.76 \mathrm{D}$ \\
\hline SF+DE 30:70 & $97 \mathrm{~A}$ & 34 A & 37 A & $4.0 \mathrm{C}$ & $11.0 \mathrm{~A}$ & $0.397 \mathrm{~B}$ & $14.55 \mathrm{C}$ \\
SF+DE+CVE 30:70 & $98 \mathrm{~A}$ & 32 A & 36 A & $4.5 \mathrm{~B}$ & $11.1 \mathrm{~A}$ & $0.380 \mathrm{~B}$ & $15.28 \mathrm{~B}$ \\
SF + MVC1 30:70 & $96 \mathrm{~A}$ & 32 A & 36 A & $5.8 \mathrm{~A}$ & $10.9 \mathrm{~A}$ & $0.440 \mathrm{~A}$ & $16.03 \mathrm{~A}$ \\
SF + MVC2 30:70 & $97 \mathrm{~A}$ & 33 A & 36 A & $5.4 \mathrm{~A}$ & $11.5 \mathrm{~A}$ & $0.419 \mathrm{~A}$ & $16.40 \mathrm{~A}$ \\
SF + MVC3 30:70 & $98 \mathrm{~A}$ & 34 A & 36 A & 5.5 A & $11.0 \mathrm{~A}$ & $0.420 \mathrm{~A}$ & $16.17 \mathrm{~A}$ \\
\hline
\end{tabular}

Different letters within each column indicate significant differences using a least significant difference (LSD) test at a significance level of $p<0.05$.

Previous research has reported significant differences in plant-growth enhancement after the application of vermicompost from diverse sources when used as an additive in soil amendment experiments. Brace [30] determined that manure-based vermicompost generally produced larger tomato and pepper plants compared to a rice-straw based vermicompost evaluated. In that study, the application of manure-based vermicompost to the soil increased tomato plant height, width, fresh weight, and Soil-Plant Analyses Development (SPAD) values when compared to the same amount of rice-straw based vermicompost mixed with the growing media. In our study, the dairy-manure based vermicompost (MVC2) had the highest value of seedling vigor index (Table 4), and was, therefore, used in the experiments 3 and 4 .

In the third set of experiments MVC2 and SF were applied to the seeds alone and in combination, to investigate their additive interaction effects compared to applications of either treatment alone, on seed germination and plant growth. Data presented in Table 5 show that percentage of total germination, the germination rate, and the uniformity were not significantly different than the non-treated seeds when SF was applied alone or in combination with MVC2. However, a significant delay was measured in germination, germination uniformity, and T50 (Table 5) when XG was used in the seed coating blend in combination with DE or MVC2. This was probably due to an increase in the hardness of the seed coat (Table A2) resulting from XG. All seed coating formulations enhanced plant growth compared to the non-treated control. Additionally, higher shoot and root lengths were measured in seed treatments of MVC2 and SF combined compared to applications of either treatment with DE or XG. The SVI calculated from the MVC and SF blended seed treatment was also significantly higher (17.5) compared to all other treatments. The combination of vermicompost with SF, application of SF alone, and vermicompost alone, increased the seedling vigor index by $40.0 \%, 29.6 \%$ and $24.8 \%$ compared to the non-treated control, respectively. Similarly, the combination of SF and MVC, and the applications of SF alone and MVC alone resulted in an increase of seedling dry matter by $37.5 \%, 21.8 \%$ and $19.0 \%$ respectively, compared to the non-treated control (Table 5).

Based on SVI data in Table 5, SF had a greater biostimulant response than XG, and MVC had a greater biostimulant effect than DE, while the combination of SF and MVC had the greatest SVI. Rouphael et al. [31] assessed the synergistic action of a commercial, microbial-based biostimulant (tablet) and a plant-derived protein hydrolysate (PH-liquid) on the growth enhancement of lettuce. A combination of microbial biostimulant with the foliar application of $\mathrm{PH}$ synergistically increased the shoot fresh weight by $22.0 \%$ and $43.3 \%$ compared to the tablet treated and non-treated plants, respectively. Their results showed that combined application of a microbial-based treatment and a plant-derived protein hydrolysate could represent an effective strategy to minimize abiotic stresses in a sustainable system [31]. 
Table 5. Mean comparisons of germination and plant growth of the MVC2 seed coating biostimulant product applied alone or in combination with different materials. Total germination (Gmax\%), germination uniformity (GU: T90-T10), germination rate (T50), shoot and root length $(\mathrm{cm})$, seedling dry weight (DWt g), and seedling vigor index (SVI $=\mathrm{Gmax} \% \times$ seedling length) of different treatments.

\begin{tabular}{cccccccc}
\hline Treatment & Gmax (\%) & GU (h) & T50 (h) & Shoot (cm) & Root (cm) & DWt (g) & SVI \\
\hline Non-treated & $96 \mathrm{~A}$ & $30 \mathrm{~A}$ & $34 \mathrm{~A}$ & $3.2 \mathrm{D}$ & $9.9 \mathrm{C}$ & $0.320 \mathrm{C}$ & $12.5 \mathrm{E}$ \\
\hline SF+DE 30:70 & $97 \mathrm{~A}$ & $31 \mathrm{~A}$ & $35 \mathrm{~A}$ & $4.5 \mathrm{~B}$ & $12.2 \mathrm{~A}$ & $0.390 \mathrm{~B}$ & $16.2 \mathrm{~B}$ \\
SF+MVC2 30:70 & $97 \mathrm{~A}$ & $32 \mathrm{~A}$ & $34 \mathrm{~A}$ & $5.7 \mathrm{~A}$ & $12.3 \mathrm{~A}$ & $0.440 \mathrm{~A}$ & $17.5 \mathrm{~A}$ \\
XG+DE 30:70 & $95 \mathrm{~A}$ & $36 \mathrm{~B}$ & $37 \mathrm{~B}$ & $3.9 \mathrm{C}$ & $10.5 \mathrm{~B}$ & $0.365 \mathrm{~B}$ & $13.6 \mathrm{D}$ \\
XG+MVC2 30:70 & $95 \mathrm{~A}$ & $36 \mathrm{~B}$ & $38 \mathrm{~B}$ & $5.5 \mathrm{~A}$ & $11.0 \mathrm{~B}$ & $0.395 \mathrm{~B}$ & $15.6 \mathrm{C}$ \\
\hline
\end{tabular}

Different letters within each column indicate significant differences using a least significant difference (LSD) test at a significance level of $p<0.05$.

In experiment set 4 , the two best seed treatments were selected to test in the greenhouse. Both treatments enhanced plant growth and development compared to the non-coated seed control plants. The highest values of plant biomass, including shoot height, dry weight, and the root length and dry weight, were observed with the vermicompost + SF followed by SF + DE application (Table 6). Seeds treated with SF+MVC2 and SF+DE produced seedlings with higher shoot and root length $-21.0 \%$ and $19.0 \%$ shoot height, and $24.0 \%$ and $20.0 \%$ root length — compared to the non-treated seeds, respectively. Both treatments significantly increased shoot dry weight by greater than $42.0 \%$ when compared to the non-treated control. The root dry weight of broccoli seedlings treated with SF+MVC2 at 30 days after planting increased growth by $51.5 \%$ when compared to the non-treated control. The same effects were observed on root dry weight for the $\mathrm{SF}+\mathrm{DE}$ treatment with a $32.3 \%$ increase in growth, compared to the non-treated control plants. However, there were no significant differences between the two treatments, but SF+MVC2 always had a highest average value (Table 6).

Table 6. The greenhouse experiment's data of biostimulant seed-coating treatments on plant growth. Parameters measured included shoot height, root length, dry weights of the shoot and root, average leaf number and total leaf area per plant, growth index, plant vigor index, and SPAD values of broccoli plants.

\begin{tabular}{|c|c|c|c|}
\hline \multirow{2}{*}{ Biometric Parameters } & \multicolumn{3}{|c|}{ Treatment } \\
\hline & Non-Treated & SF+DE 30:70 & SF+MVC2 30:70 \\
\hline Shoot height (cm) & $17.2 \pm 1.4 \mathrm{~B}$ & $20.5 \pm 1.3 \mathrm{~A}$ & $20.8 \pm 1.4 \mathrm{~A}$ \\
\hline Shoot Dry Wt (g) & $1.273 \pm 0.20 \mathrm{~B}$ & $1.815 \pm 0.20 \mathrm{~A}$ & $1.824 \pm 0.25 \mathrm{~A}$ \\
\hline Root length (cm) & $24.6 \pm 2.5 \mathrm{~B}$ & $29.5 \pm 2.4 \mathrm{~A}$ & $30.5 \pm 1.0 \mathrm{~A}$ \\
\hline Root Dry Wt g & $0.539 \pm 0.20 \mathrm{~B}$ & $0.713 \pm 0.16 \mathrm{AB}$ & $0.817 \pm 0.15 \mathrm{~A}$ \\
\hline Total Leaf Area $\left(\mathrm{cm}^{2}\right)$ & $249.5 \pm 33.0 \mathrm{~B}$ & $292.0 \pm 41.0 \mathrm{~A}$ & $304.5 \pm 45.0 \mathrm{~A}$ \\
\hline Leaf number (no plant ${ }^{-1}$ ) & $5.00 \pm 0.1 \mathrm{C}$ & $5.6 \pm 0.3 \mathrm{~B}$ & $5.9 \pm 0.2 \mathrm{~A}$ \\
\hline Growth Index & $17.6 \pm 1.1 \mathrm{~B}$ & $21.4 \pm 1.3 \mathrm{~A}$ & $21.9 \pm 1.5 \mathrm{~A}$ \\
\hline Plant Vigor Index & $41.8 \pm 2.4 \mathrm{~B}$ & $50.0 \pm 3.4 \mathrm{~A}$ & $51.3 \pm 2.9 \mathrm{~A}$ \\
\hline SPAD & $50.0 \pm 2.1 \mathrm{C}$ & $55.4 \pm 2.5 \mathrm{~B}$ & $58.0 \pm 2.3 \mathrm{~A}$ \\
\hline
\end{tabular}

Different letters within each row indicate significant differences using a least significant difference (LSD) test at a significance level of $p<0.05$. The results are presented as the means \pm standard deviations.

The combination of vermicompost with SF, and application of SF alone, increased the total leaf area by $22.0 \%$ and $17.0 \%$ respectively, compared to the non-treated control. Both treatments also had higher total leaf numbers (Table 6) and percentages of plants with six developed leaves (Figure 3) in 30 days. Eighty-four percent of seedlings produced from SF+MVC2 coated seeds, had six developed leaves, while only $68 \%$ of SF+DE had six leaves, and both had better overall growth compared to the non-treated plants. Only $4 \%$ of seedlings had six developed leaves in the control plants (Figure 3). 


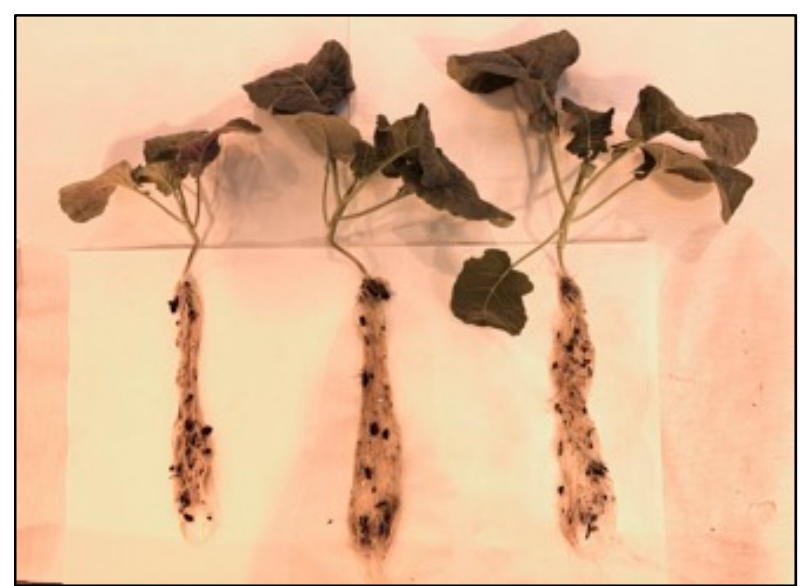

Non-treated, SF+DE, SF+MVC 2

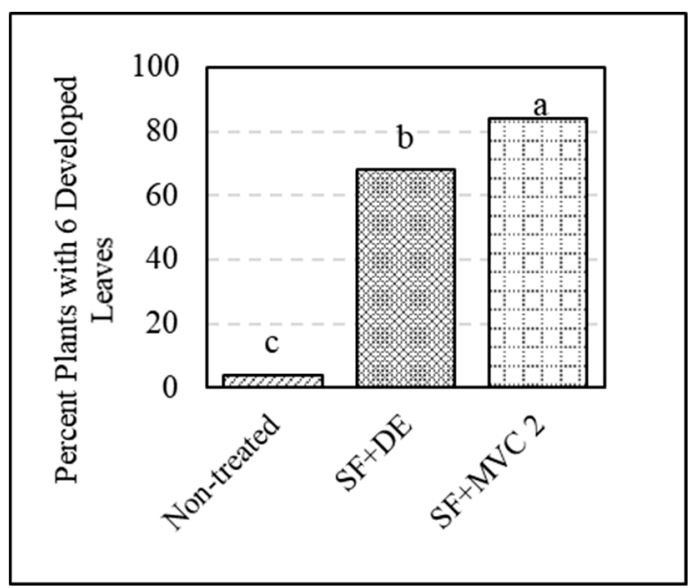

(B)

(A)

Figure 3. (A) The effects of different treatments 30 days after planting on above and below ground plant growth, and (B) the percentages of plants with six developed leaves.

The growth index - an indicator of above ground growth, and the plant vigor index-a product of seed germination, and above and below ground growth, had a strong positive linear relationship $\left(\mathrm{R}^{2}=0.76^{* *}\right)$ (Figure $\left.4 \mathrm{~B}\right)$ indicating that the biostimulant seed coating applications enhanced total plant growth.
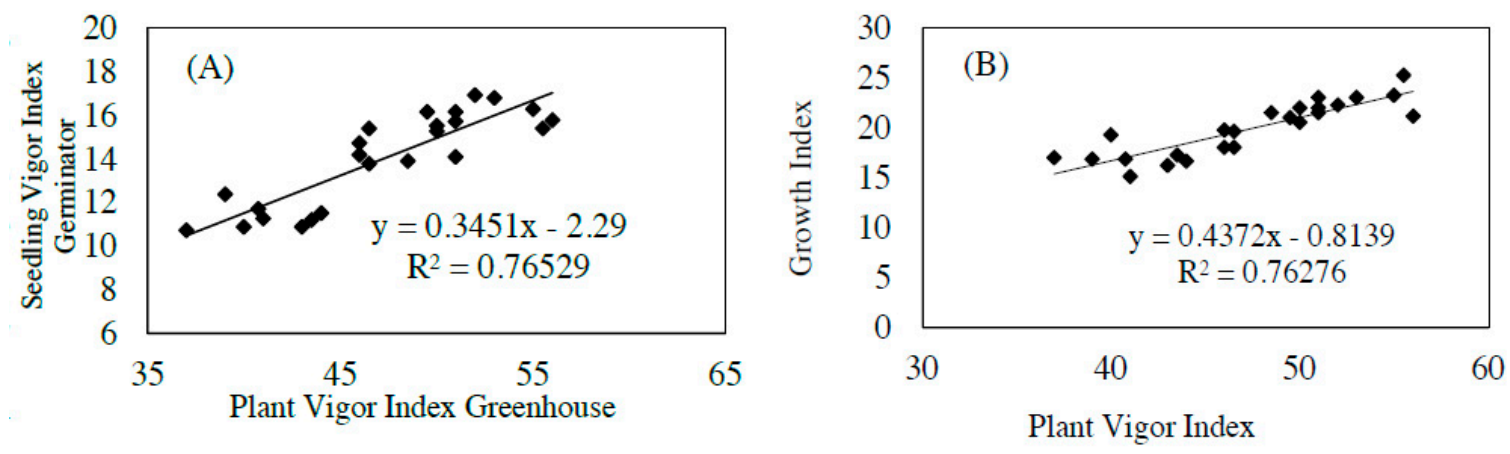

Figure 4. Linear relationships of (A) the seedling vigor index of the germinator's data, with plant vigor index of the greenhouse's data $\left(\mathrm{R}^{2}=0.76^{* *}\right)$. (B) The growth index and plant vigor index of the greenhouse experiment $\left(R^{2}=0.76^{* *}\right)$.

The biostimulant application enhancement on plant biometric and morphological parameters was also reflected in plant physiological measurements. In addition to enhanced plant growth, the $\mathrm{SF}+\mathrm{MVC} 2$ treated plants had the highest SPAD values (58.0) at 30 days, followed by the SF+DE (55.4) treatment, and the lowest numbers (50.0) were recorded in the non-coated seed control plants (Table 6). Several earlier studies have shown that seed treatments, and soil and foliar applications of biostimulants, have beneficial effects on photosynthesis on broccoli, tomato, and oilseed rape crops $[5,32,33]$. Higher SPAD readings recorded in both treatments in this study compared to the non-treated control plants could be in the result of enhanced nitrogen uptake. Research on different sources of biostimulants in wide varieties of crops, concluded that the SPAD unit is an important indicator of chlorophyll and nitrogen content, which have both been correlated with crop quality and performance $[34,35]$.

Overall, our results showed that application of a plant-based biostimulant alone and in combination with a vermicompost directly onto the seeds, improved broccoli plant performance, produced more vigorous seedlings, and enhanced nitrogen uptake compared to the non-treated seeds. A combined 
application of these materials also (SF+MVC2) resulted in plants with higher numbers of leaves and chlorophyll synthesis (Figure 3 and Table 6). In addition, seedling vigor indices from the laboratory and plant vigor indices of the greenhouse experiments (Figure $4 \mathrm{~A}$ ) showed a strong positive linear relationship $\left(R^{2}=0.76^{* *}\right)$, suggesting that the 10-day roll towel test in a laboratory germinator can predict growth enhancement of a 30-day old plant in the greenhouse.

The results of current study are in agreement with several studies that demonstrated the positive effects of plant-derived protein biostimulant alone [5,36], microbial-based biostimulant alone [6], or plant and microbial-based biostimulants in combination [31], on higher nutrient uptake, better shoot and root development and the enhancement of crop performance. Application of a commercial protein hydrolysate improved the dry weights of shoots and roots, and the total biomass of tomato plants due to enhanced nitrogen uptake and upregulation of primary enzymes involved in N metabolism [36]. Amirkhani et al. [5] reported earlier that coating broccoli (Brassica oleracea (var. Italica 'Centura')) seeds with SF and cellulose fibers increased plant biomass and nitrogen uptake efficiency. They concluded that $\mathrm{N}$ applied in the seed coating materials only accounted for $1-2 \%$ of the increased nitrogen in plants, while in the present study, the application of SF+DE and SF+MVC2 accounted for $3.3 \%$ and $5.1 \%$ of the enhanced nitrogen in plant tissues, respectively (Figure 5). This difference may be due to specific cultivar, or a difference in seed coating methods or greenhouse growing media. Moreover, both studies indicated that SF, which is quite inexpensive, acted as an excellent biostimulant with only a minor role as nitrogen fertilizer.

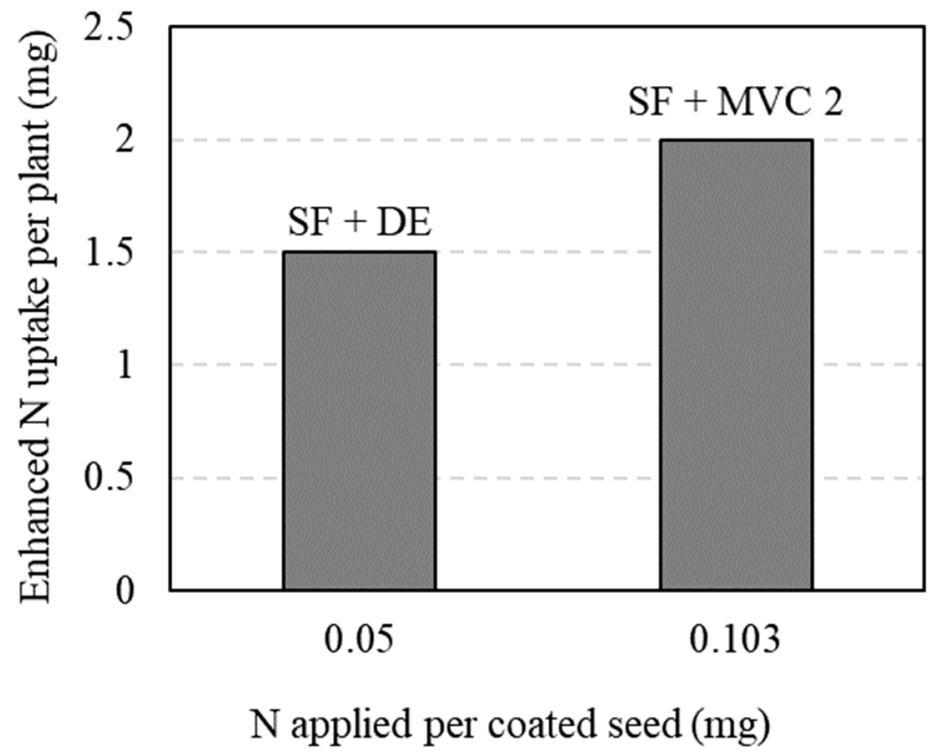

Figure 5. Enhanced nitrogen uptake per plant (30 day old plants), and applied nitrogen per coated seed.

\section{Conclusions}

In summary, the development of a new and effective delivery system via the seed coating of biostimulant compounds for a high value, small seeded vegetable crop 'broccoli' was achieved. Plant biometric parameters and nitrogen uptake per plant were significantly greater for SF and SF+MVC coated seeds than the control, in the greenhouse. SF alone and in combination with MVC acted as an excellent biostimulant. Coating broccoli seeds with vermicompost and soy flour showed no negative effect on germination parameters, and did not reduce total germination or delay the germination rate of seeds when compared to non-treated seeds. However, the results of these studies clearly showed that the seed coating delivery system with $30 \%$ build up around the seed with the co-application of two biostimulants as a seed coating blend, with no liquid binder, resulted in a greater enhancement in early plant growth than when each component was applied separately. This approach can be used as an effective green management practice for sustainable crop production. The mechanical integrity 
characteristics of the seed coating formulations developed in this study would be important for the commercialization of biostimulant seed-coating materials. The seed coatings developed in this study can serve as a model for development of delivery systems, on seeds, for the application of bio-based biostimulants to enhance plant growth in diverse crops. Additional research, however, is needed to determine if these types of seed treatments can influence crop yield in field trials.

Author Contributions: M.A. Investigation, experimental design, data collection and analysis, writing and original draft preparation. A.G.T. and A.N.N. Conceptualization, funding acquisition and editing the manuscript. H.S.M. Critically review and editing of the manuscript.

Funding: This material is based upon work that is supported by the United States Hatch Funds under accession \#1007492 to the third and fourth authors, and Multi-state Project W-3168, under accession \#1007938 to the fourth author.

Acknowledgments: The authors thank Michael T. Loos for his technical assistance and comments during the experiments in the laboratory and greenhouse.

Conflicts of Interest: The authors declare no conflict of interest.

\section{Appendix A}

Table A1. Correlation coefficients of disintegration time (DT, $\mathrm{min}$ ), weight loss (WL, \%), compressive strength (Force, N), and time to decay (TD, s) with germination uniformity $(\mathrm{GU}, \mathrm{h})$, and rate (T50, h) from seed coating applications in experiment 1 .

\begin{tabular}{|c|c|c|c|c|}
\hline Treatment & DT (min) & WL (\%) & TD (s) & Force $(\mathrm{N})$ \\
\hline GU (h) & $+0.99 * * *$ & $-0.97^{* * *}$ & $+0.99 * * *$ & $+0.98^{* * *}$ \\
\hline T50 (h) & $+0.93^{* *}$ & $-0.97^{* * *}$ & $+0.93 * *$ & $+0.97^{* * *}$ \\
\hline DT (min) & - & $-0.97^{* * *}$ & $+0.99 * * *$ & $+0.98^{* * *}$ \\
\hline WL (\%) & - & - & $-0.97^{* * *}$ & $-0.98^{* * *}$ \\
\hline
\end{tabular}

Table A2. The mechanical properties of seed coating formulas used in this study: weight loss (WL, \%), disintegration time (DT min), compressive strength (Force, N), and time to decay (TD, s).

\begin{tabular}{ccccc}
\hline Treatment & WL (\%) & DT (min) & Force (N) & TD (s) \\
\hline SF+DE+CVE 30:70 & $1.4 \mathrm{~B}$ & $70 \mathrm{C}$ & $16.8 \mathrm{C}$ & $0.41 \mathrm{C}$ \\
SF + MVC1 30:70 & $1.5 \mathrm{~B}$ & $75 \mathrm{BC}$ & $17.2 \mathrm{BC}$ & $0.52 \mathrm{~B}$ \\
SF + MVC3 30:70 & $1.5 \mathrm{~B}$ & $78 \mathrm{~B}$ & $19.0 \mathrm{BC}$ & $0.50 \mathrm{~B}$ \\
XG+MVC1 30:70 & $0.4 \mathrm{~A}$ & $183 \mathrm{~A}$ & $21.0 \mathrm{~A}$ & $1.50 \mathrm{~A}$ \\
XG+DE 30:70 & $0.6 \mathrm{~A}$ & $178 \mathrm{~A}$ & $20.0 \mathrm{AB}$ & $1.31 \mathrm{~A}$ \\
\hline
\end{tabular}

Different letters within each row indicate significant differences using a least significant difference (LSD) test at a significance level of $p<0.05$.

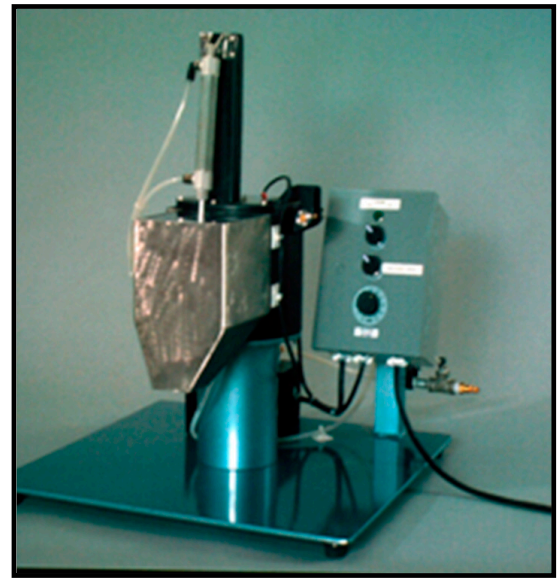

(A)

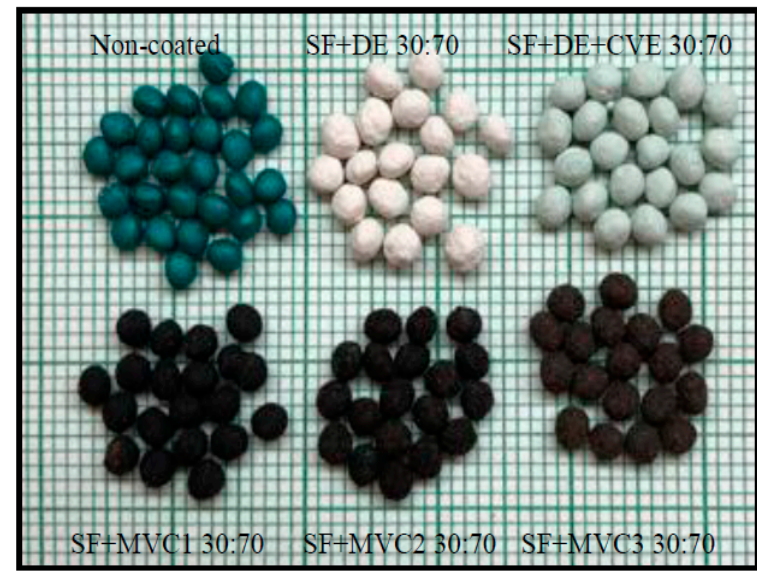

(B)

Figure A1. (A) Rotary pan coater-R6 and (B) non-coated and coated seeds of broccoli from experiment 2. 


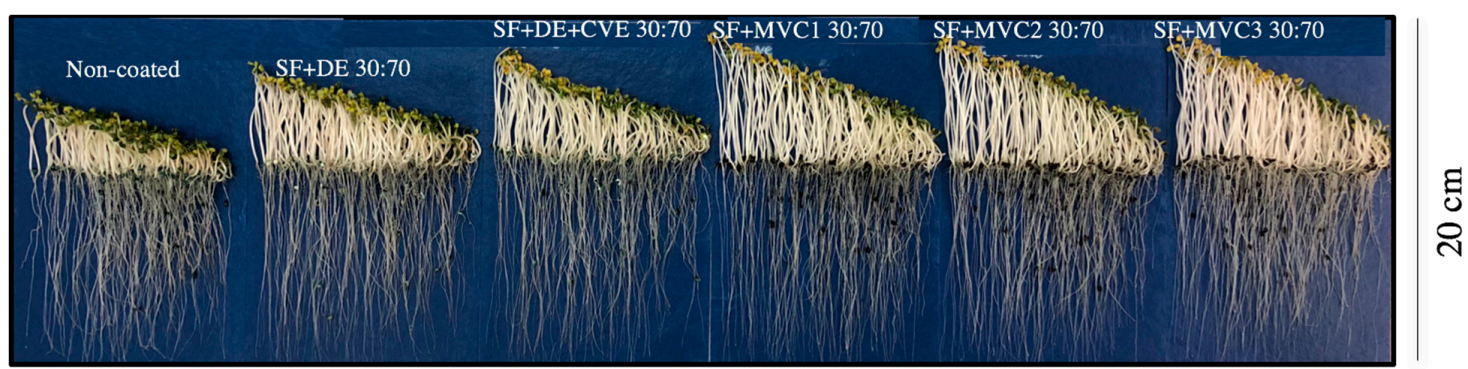

Figure A2. The seedling growth of different treatments from experiment 2, 10 days after planting in a roll towel under germinator conditions.

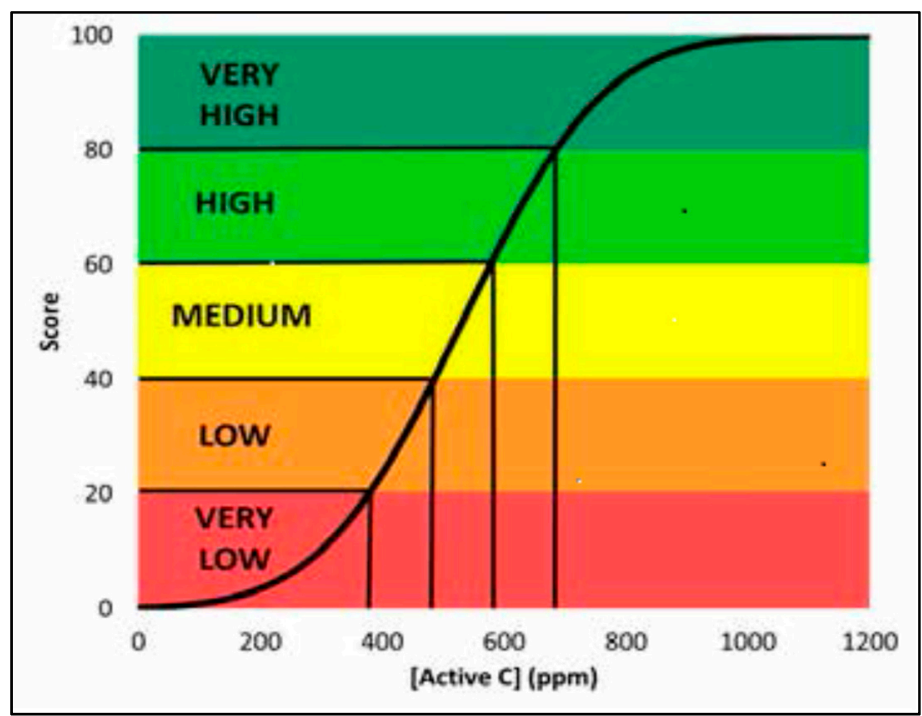

Figure A3. Cornell's soil health lab's respiration chart [17]. http://soilhealth.cals.cornell.edu.

\section{References}

1. Jardin, D.P. Plant biostimulants: Definition, concept, main categories and regulation. Sci. Hort. 2015, 196, 3-14. [CrossRef]

2. Calvo, P.; Nelson, L.; Kloepper, J.W. Agricultural uses of plant biostimulants. Plant Soil 2014, 383, 3-41. [CrossRef]

3. Yakhin, O.I.; Lubyanov, A.A.; Yakhin, I.A.; Brown, P.H. Biostimulants in plant science: A global perspective. Front. Plant Sci. 2016, 7, 2049. [CrossRef] [PubMed]

4. Xu, L.; Geelen, D. Developing biostimulants from agro-food and industrial by-products. Front. Plant Sci. 2018, 9, 1567. [CrossRef] [PubMed]

5. Amirkhani, M.; Netravali, A.N.; Huang, W.; Taylor, A.G. Investigation of soy protein-based biostimulant seed coating for broccoli seedling and plant growth enhancement. HortScience 2016, 51, 1121-1126. [CrossRef]

6. Ma, Y.; Látr, A.; Rocha, I.; Freitas, H.; Vosátka, M.; Oliveira, R.S. Delivery of inoculum of rhizophagus irregularis via Seed Coating in Combination with Pseudomonas libanensis for Cowpea Production. Agronomy 2019, 9, 33. [CrossRef]

7. Farooq, M.; Wahid, A.; Kadambot, H.M.S. Micronutrient application through seed treatments-A review. J. Soil Sci. Plant Nutr. 2012, 12, 125-142. [CrossRef]

8. Halmer, P. Methods to improve seed performance in the field. In Handbook of Seed Physiology: Applications to Agriculture; Benech-Arnold, R.L., Sanchez, R.A., Eds.; Haworth Press: New York, NY, USA, 2004; pp. 120-156.

9. Wilson, H.T.; Amirkhani, M.; Taylor, A.G. Evaluation of gelatin as a biostimulant seed treatment to improve plant performance. Front. Plant Sci. 2018, 9, 1006. [CrossRef] 
10. Aremu, A.O.; Stirk, W.A.; Kulkarni, M.G.; Tarkowska, D.; Tureckova, V.; Gruz, J.; Šubrtová, M.; Pěnčík, A.; Novák, O.; Doležal, K.; et al. Evidence of phytohormones and phenolic acids variability in garden-waste-derived vermicompost leachate, a well-known plant growth stimulant. Plant Growth Regul. 2015, 75, 483-492. [CrossRef]

11. Hussain, N.; Abbasi, S.A. Efficacy of the vermicomposts of different organic wastes as "Clean" Fertilizers: State-of-the-Art. Sustainability 2018, 10, 1205. [CrossRef]

12. Taylor, A.G.; Allen, P.S.; Bennett, M.A.; Bradford, K.J.; Burris, J.S.; Misra, M.K. Seed enhancements. Seed Sci. Res. 1998, 8, 245-256. [CrossRef]

13. Hutmacher, B.; Keeley, M.; Marsh, B.; Rothrock, C. Seed Fungicide Treatment Trials-Update and Data Summary; University of California Cooperative Extension: Davis, CA, USA, 2005.

14. Schmitt, A.; Koch, E.; Stephan, D.; Kromphardt, C.; Jahn, M.; Krauthausen, H.J. Evaluation of non-chemical seed treatment methods for the control of Phomavalerianellaeon lamb's lettuce seeds. J. Plant Dis. Prot. 2009, 116, 200-207. [CrossRef]

15. Gerhardson, B. Biological substitutes for pesticides. Trends Biotechnol. 2002, 20, 338-343. [CrossRef]

16. Knowles, A. Recent development of safer formulations of agrochemicals. J. Environ. 2008, $28,35-44$. [CrossRef]

17. Moebius-Clune, B.N.; Moebius-Clune, D.J.; Gugino, B.K.; Idowu, O.J.; Schindelbeck, R.R.; Ristow, A.J.; Van Es, H.M.; Thies, J.E.; Shayler, H.A.; McBride, M.B.; et al. Comprehensive Assessment of Soil Health-The Cornell Framework, 3rd ed.; Cornell University: Geneva, Switzerland; New York, NY, USA, 2017; 134p.

18. Texture Analysis. Texture: Measure and Analyze Properties. Disintegration. Available online: https: //www.stablemicrosystems.com/MeasureDisintegration.html (accessed on 18 March 2019).

19. AOSA. Rules for testing seeds. Principles and procedures. Assn. Off. Seed Anal. 2014, 1, 6-25.

20. Egli, D.B.; Hamman, B.; Rucker, M. Seed vigor and uniformity of seedling emergence in soybean. Seed Technol. 2010, 32, 87-95.

21. Coolbear, P.; Francis, A.; Grierson, D. The effect of low temperature pre-sowing treatment on the germination performance and membrane integrity of artificially aged tomato seeds. J. Exp. Bot. 1984, 35, 1609-1617. [CrossRef]

22. Abdul-Baki, A.A.; Anderson, J.D. Vigor determination in soybean seed by multiple criteria. Crop Sci. 1973, 13, 630-633. [CrossRef]

23. Guo, Y.; Niu, G.; Starman, T.; Volder, A.; Gu, M. Poinsettia growth and development response to container root substrate with biochar. Horticulturae 2018, 4, 1. [CrossRef]

24. Lea-Cox, J.D.; Syvertsen, J.P. How nitrogen supply affects growth and nitrogen uptake, use efficiency, and loss from citrus seedlings. J. Am. Soc. Hort. Sci. 1996, 121, 105-114. [CrossRef]

25. Krishnamoorthy, R.V.; Vajrabhiah, S.N. Biological activity of earthworm casts: An assessment of plant growth promoter levels in casts. Proc. Indian Acad. Sci. USA 1986, 95, 341-351. [CrossRef]

26. Kim, J.T.; Netravali, A.N. Performance of protein-based wood adhesives and development of small scale test method for characterizing adhesive tensile properties. J Adhes. Sci. Technol. 2012, 27, 2083-2093. [CrossRef]

27. Kim, J.T.; Netravali, A.N. Mechanical, thermal, and interfacial properties of green composites with ramie fiber and soy resins. J. Agric. Food Chem. 2010, 58, 5400-5407. [CrossRef] [PubMed]

28. Foqué, D.; Devarrewaere, W.; Verboven, P.; Nuyttens, D. Physical and chemical characteristics of abraded seed coating particles. Asp. Appl. Biol. 2014, 122, 85-94.

29. Nuyttens, D.; Devarrewaere, W.; Verboven, P.; Foqué, D. Pesticide-laden dust emission and drift from treated seeds during seed drilling: A review. Pest Manag. Sci. 2013, 69, 564-575. [CrossRef]

30. Brace, S.A. Vermicompost Application as a Fertilizer Source and Substrate Amendment for Seedling and Transplants: Practical Application and Microbial Activity Analysis. Ph.D. Thesis, Cornell University, Ithaca, NY, USA, 2017.

31. Rouphael, Y.; Cardarelli, M.; Bonini, P.; Colla, G. Synergistic action of a microbial-based biostimulant and a plant derived-protein hydrolysate enhances lettuce tolerance to alkalinity and salinity. Front. Plant Sci. 2017, 8, 131. [CrossRef] [PubMed]

32. Sestili, F.; Rouphael, Y.; Cardarelli, M.; Pucci, A.; Bonini, P.; Canaguier, R.; Colla, G. Protein hydrolysate stimulates growth in tomato coupled with $\mathrm{N}$-dependent gene expression involved in $\mathrm{N}$ assimilation. Front. Plant Sci. 2018, 9, 1233. [CrossRef] [PubMed] 
33. Przybysz, A.; Gawrońska, H.; Gajc-Wolska, J. Biological mode of action of a nitrophenolates-based biostimulant: Case study. Front. Plant Sci. 2014, 5, 713. [CrossRef]

34. Colla, G.; Cardarelli, M.; Bonini, P.; Rouphael, Y. Foliar applications of protein hydrolysate, plant and seaweed extracts increase yield but differentially modulate fruit quality of greenhouse tomato. HortScience 2017, 52, 1214-1220. [CrossRef]

35. Ertani, A.; Schiavon, M.; Nardi, S. Transcriptome-wide identification of differentially expressed genes in Solanum lycopersicon L. in response to an alfalfa-protein hydrolysate using microarrays. Front. Plant Sci. 2017, 8, 1159. [CrossRef]

36. Colla, G.; Rouphael, Y.; Canaguier, R.; Svecova, E.; Cardarelli, M. Biostimulant action of a plant-derived protein hydrolysate produced through enzymatic hydrolysis. Front. Plant Sci. 2014, 5, 448. [CrossRef] [PubMed]

(C) 2019 by the authors. Licensee MDPI, Basel, Switzerland. This article is an open access article distributed under the terms and conditions of the Creative Commons Attribution (CC BY) license (http://creativecommons.org/licenses/by/4.0/). 